\title{
Research on the Reconstruction of Rural Settlement Ecosystem ---Take Han Zhong Resettlement Area as an Example
}

\author{
Huang Yan*
}

Civil Engineering and Architecture Dept, Shaanxi University of Technology, Hanzhong 723001, Shaanxi, P.R. China

\begin{abstract}
The ecological reconstruction forms and methods of rural settlements were explored in the paper. The construction project of Hedong town resettlement was as research subject in order to reconstruct the traditional rural settlements. The location settlement, settlement distribution form and space of street, and the reconstruction of ecological architecture system were used as research method. The results indicated properties of town were retained. Uncomfortable feel of villagers eliminated when they moved in a new environment. Living conditions are improved. These experiences can be subsequent reference to other similar projects.
\end{abstract}

Keywords: Rural settlement ecosystem, HanZhong, reconstruction.

\section{INTRODUCTION}

Settlement is the center of human activity, both people to live, to rest and to carry out various social activities, places, people also carry out production work places [1]. The traditional rural settlements is the basic place for people to live and produce by residential streets and other production and living facilities constitutes. Due to the local natural environment, geographical conditions, social economy and cultural development extent, the settlement exhibit different characteristics [2]. In particular, the migrants project for the south, a policy of this immigration, involving a wide range of short duration, a number of people, often more than one project at the same time, with its own immigration policy exhibit integrity, and villagers ' low spontaneity, coupled with a huge project, in resettlement planning and construction, prone to "thousands of village side", "barracks-style layout," the embarrassing situation, the lack of village landscape characteristics of performance, ignoring traditional rural settlement landscape heritage and continuity, fragmentation villagers homes nostalgic feelings [3].

Therefore, it should be fully aware of the rural regional characteristics of homogeneity and universality, and show the comparison between regional heterogeneity and particularity, and fully absorb the regional landscape elements, such as historical heritage, living habit and production, unique folk custom and so on, combined with modern life and behavior, to create a pastoral landscape of the village landscape [4].

\section{PROJECT BACKGROUND}

The resettlement area construction project of HeDong Town in Hanzhong city is a part of the southern of Shaanxi relocation project. Southern relocation project implementation mainly due to geological conditions in Southern Mountainous extremely unstable and prone to geological disasters (landslides, mudslides, etc.), and farmers' difficult living conditions, inconvenient traffic, so it is a threat to mountain people life and property safety.

In this paper, from the site's location planning, ecological architecture design inheritance and development of research on the subjects such as technology, from the perspective of new discipline to discover and solve problems, try to based on the perspective of architecture, planning, landscape and other interdisciplinary to in-depth study, and trying to change the "thousand village side", "barracks type" of the construction of the situation, to create a pleasant settlement space and landscape, and to creat immigrants to their homes.

\section{PROJECT OVERVIEW}

He Dong Town resettlement area located near the State Road 316, shown in Fig. (1), north of the city planning road, covering 64 acres, building area of 65,000 square meters, planning resettlement 682,2455 people. The planning has two major roads, the land was divided into four parts, which were divided into residents southeastern centers and community cultural and recreational activities office room, the other three groups were residential and commercial outlets and other sites, architectural forms using imitation style houses, illustrated black tiles are 6 floors for residential, gray tile 1 or two layers public buildings, arranged around the housing. Planning area traffic flow line simple and clear, but things between the road to the house were blocked shops, forming broken end, formally creating a relatively closed space, typical of the "barracks-style layout." Area building regular and consistent volume, lack of space beauty.

From planning and architectural design of the various economic and technical indicators, which was designed to meet the relevant national norms and local regulations, with the planning, design and construction of industrial advantages, security, economic, practical and consistent with the 


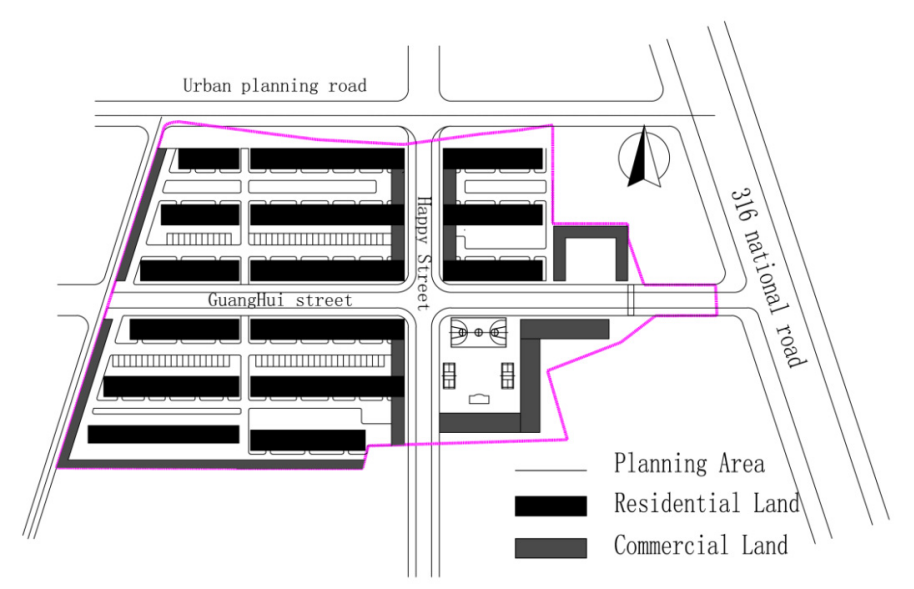

Fig. (1). The planning of resettlement area construction project of HeDong Town.

basic principles of modern residential design. But with the change in residential design trends, not only for the crowd settlement functions, and to meet people's most basic living requirements, but after living meet the requirements, returning to the higher demands of natural, user-friendly design, etc. and retrospective design of the essence of Chinese traditional settlements. Therefore, from the settlement below the site, the village of ecosystems, and create and vernacular architecture and context of the continuation of settlement layout and other forms of street space and Southern traditional settlement landscape features several key aspects to further refine the reconstruction.

\section{HEDONG TOWN RURAL RESETTLEMENT SITES OF ECOLOGICAL RECONSTRUCTION SETTLE- MENT}

Southern Mountainous Rural Settlement site follow the traditional Chinese landscape and pastoral village sitting requirements, settlement and integration of the natural environment, mountain water, natural landscape pattern has become an important trait of rural settlement landscape, and in line with people's spatial scales [5].

As shown in Fig. (2), follow the "Heaven" philosophy, and seek for a state sitting base in harmony with nature, and in line with the traditional Chinese "landscape" feelings of psychological needs. Although the villagers at once spontaneous migration does not take into account the various types of disaster risks in Southern mountainous geological instability caused, one on the village site, and fronting water and with hills on the back, conducive to withstand winter winds, low-lying villages before the summer running water or ground can promote air circulation, hillside farmhouse can get good sunshine, mountains, water, forest, land and other elements to form a good natural ecosystems, it is the performance of man and nature in harmony.

The example in this article is sitting near State Road 316, completely solved the traffic problems for disaster prevention and planning and architectural design, industry is also in line with the technical requirements of the relevant national and local norms, but it is located in flat, open land, can not formally meet according to the traditional Southern mountain village "fronting water and with hills on the back" sitting factors, winter can not stop the wind, summer is the wind because of the closure of the planning and design unable to penetrate the cell, sunlight conditions and also because of the high volume rate building density is affected, can not be compared to traditional villages of natural ecosystems.

Therefore, the ecological reconstruction of settlements settlements focused on the following aspects:

\subsection{Reconstruction of Settlement Layout Form}

Forming each village, there is a natural evolution, as well as their natural conditions and historical background, selfcontained, the formation of different styles of building lay-

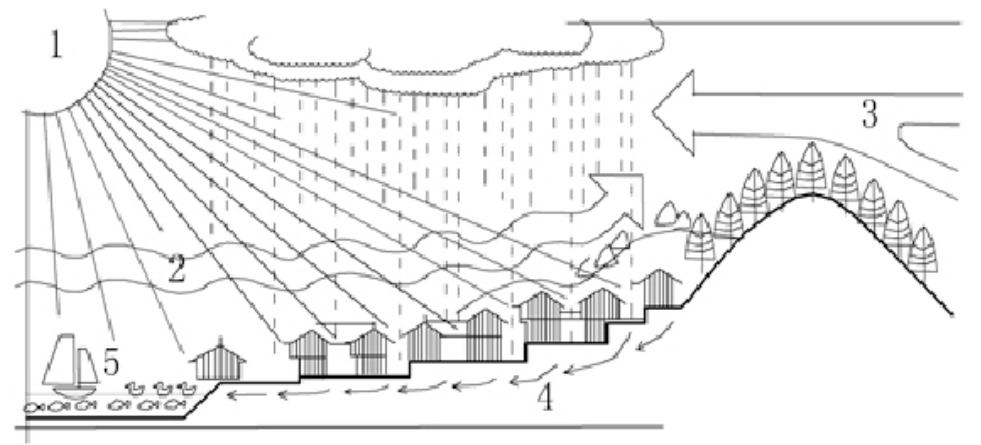

Fig. (2). Settlement ecosystem.

Notes: 1 . Better sunlight; 2. Accept the summer wind of south; 3. Obstruct the winter cold of airflow; 4. Better drainage; 5 . Keep adjusting micro climate. 
out, the road system and spatial form, the so-called "learning from nature" is true [6]. The villagers by using different natural and geographical conditions, and gradually form different forms of settlement form, for example in the field of rural settlements between flatland region, affected by land, was massive distribution; the hilly terrain mountainous settlements, traffic line constraints and rivers attract, linearly distributed; there are a few in the high mountain settlements scattered type, distributed by the topography impact, mainly as a family or a few families gathered settlements, scatter arrangement or form small aggregates villages.

Resettlement planning and design is due to time constraints, extensive management, plots of different sizes, workload and other reasons, mostly structured design, was "barracks-style" layout [7]. Planning area, north-south and east-west trunk road each one, three secondary roads northsouth, east-west between the house along the road due to the housing arrangement, relatively dense, but only the main road leading to the base, the other roads are broken road, lack of contact with each other, this arrangement features a clear, flow line clear, high utilization, but the layout of the form is too smooth, the lack of space for the villagers to stay settlements, lack of affinity and life [8].

So it can meet the economic and technical indicators of the premise, with mountainous areas in southern Shaanxi form of settlement, the former residence of redrafting the natural flow of all types of flow lines, forming a person walking in the landscape between the touching scene. As shown in Fig. (3), without changing the volume ratio of the premise, to fine-tune the building density, adjust the length of the building combined splicing, appropriate path toward change, which will be the evolution of the main north-south axis three times successively in contact axis, transportation and rich residential area landscape axis, to strengthen the links between things anterior to the house, residents of transitional space for the exchange of the enclosure, while the Northeast to the group select Add a north-south road between the house, in order to enrich a relatively closed space, increase the "barracks-style" design lacks walking scene node, enhance communication between the occupants and the environment, make the "barracks-style" design more pleasant.

\subsection{Reconstruction of Settlement Street Space}

Southern Mountainous Rural Settlement features a single, mostly living mainly business functions, supplemented, located in the river or the Hill side, the land is limited, rural settlement road system adapted to local conditions, mountain, street with undulating terrain, full turn changes, maintaining the original characteristics of the terrain, "From the person, because of its land, all their days" [9]. Mainly street is generally distributed along the mountain or river, bear transportation, markets function, building street layout, standing opposite, mostly shops, market form, side-phase clusters, forming a narrow roadway, the external and internal space settlements clever segmentation. Since transport is simple, small traffic, pedestrian traffic are mainly pleasant spatial scale, filled with slow-paced life style, emotional narrative tradition of neighborhood life. Under the combined effect of changing the vertical and horizontal shaping South-

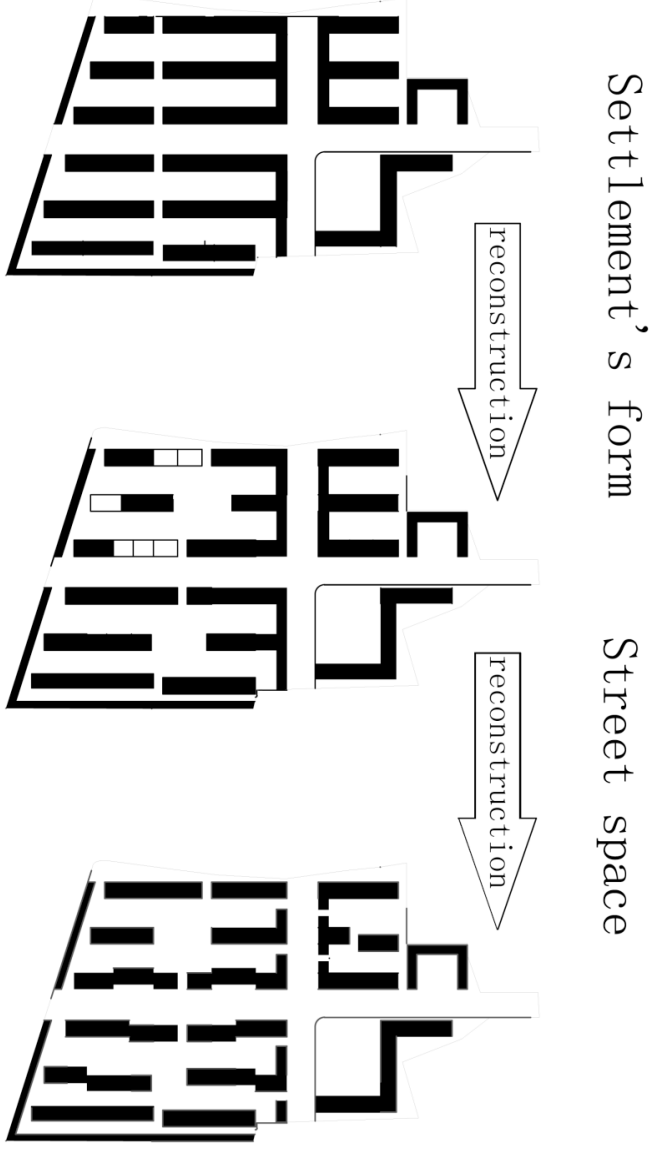

Fig. (3). The relationship between figure and ground of Settlement pattern and street space reconstruction.

ern mountainous rural settlements streets rich spatial variations and charm [10].

Ashihara Yoshinobu said in its "exterior space design" in the "outer space, every $20 \sim 25 \mathrm{~m}$, it should be repeated with spatial rhythm, diversity performance and changes in topography [11]. Therefore, deepening the design process, using Fig. (4), the adjustment path in the direction and width in order to distinguish between "street" and "lane" sense of space scales, as well as primary and secondary public space, a space sequence gradual, and create space communication between neighborhoods and improve public participation activities in the region, in order to mitigate the psychological pressure of the new environment does not apply. Such as the north and south sides of the main road to leave some space to shop, as a transitional space groups inside and outside connections, strengthen the links between the streets, not only to undermine the traffic flow lines, but also to reduce the original space is too closed a sense of depression, easy summer southerly from the transitional space between the street penetrated into the interior tour, meet the villagers long Language mountains and the natural environment everywhere exchanges, walking scene atmosphere of life fundamentally [11].

\subsection{Settlement Sunshine and Ventilation Upgrade}

Southern Rural traditional settlement due to the small building density, low-rise residential buildings, mostly, good 


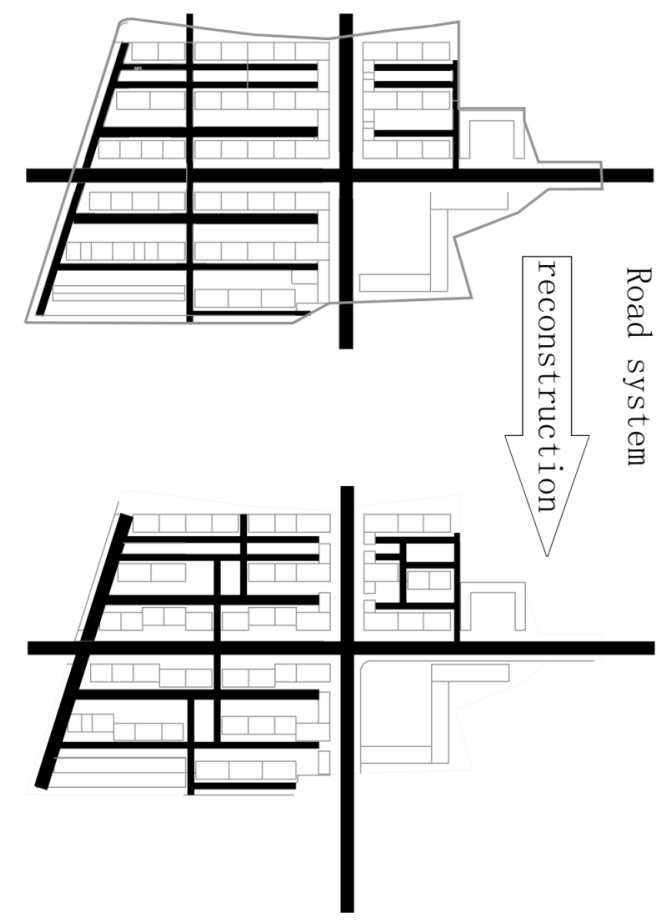

Fig. (4). The road system reconstruction.

sunlight conditions, particularly those situated in hilly or mountain areas of settlement, mostly due to the settlement in the form layout scatter layout, its sunshine basic conditions without any factors, but the yard surrounding trees planted for shade in summer, while winter demand does not affect the lighting [12].

The planning of He Dong settlements, in line with the current residential area planning and design standards, to meet the minimum requirements of the winter sunshine, but compared to the immigrant origin of sunlight conditions, immigration can only be out of the building, can enjoy with similar origin conditions. Therefore, we can choose to ascend the north side of the building's height, or to artificially create slope, land use planning to reduce the shortcomings of too gentle, even they can not do residential use on the first floor on the north side tour of the building, increasing the space residents, reducing households affected by the underlying everyday life of poor sunlight conditions.

Reconstruction process, without changing the volume ratio and building density, only by adjusting the height of the building, the use of layers of addition and subtraction, lift height on the north side of residential central building remained unchanged, while the south side of the building height gradually reduce and expand the courtyard space; or use the form artificial slopes, improve the north building elevation; or choose larger size arranged in the north of the trees, blocking winter winds. We choose to use resettlement area Ecotect software simulation environment, select sunshine average total radiation and thermal comfort (mean radiant temperature) two indicators to illustrate changes in sunlight conditions, as shown, whereupon the average amount of radiation resettlement area of the original plan for the whole of sunshine $1540.43 \mathrm{wh}$, mean radiant temperature $22.03 \mathrm{wh}$, and after the program adjustments, the average amount of solar radiation for the whole resettlement areas $1660.21 \mathrm{wh}$, mean radiant temperature of $23.55^{\circ} \mathrm{C}$, explained after adjustment, the local sunlight conditions have improved significantly.

We improved the settlements of natural ventilation rates and daylighting rate, and improved settlements microecosystem, and achieved the purpose of building the microclimate regulation by using different heights of the building, both extended daylight time, while maintained the shelter cold winter, cool in summer guide into the area to remove heat effect, the formation of the ecosystem traditional village landscape patterns.

\section{EPILOGUE}

Although settlements reconstruction approach can not completely generic, we can learn by adjusting the ecological relationship between the settlement and the environment, the concept of ecological relationships between man and settlement environment, and promoting the occupants in harmony with nature, "Seeing "poetic expression of the traditional atmosphere of life settlements, prompting the construction of settlements is more pleasant, so that the villagers have long maintained a tactful life held in the traditional landscape space subtle, simple emotions, and can be in the new home " stay" live [13].

\section{CONFLICT OF INTEREST}

The authors confirm that this article content has no conflicts of interest.

\section{ACKNOWLEDGEMENT}

Declared none.

\section{REFERENCES}

[1] R. Picone, "Vernacular Architecture: Towards a Sustainable Future - Proceedings of the International Conference on Vernacular Heritage," Sustainability and Earthen Architecture, ppl.625-630, 2015.

[2] P. Touzel, "Managing environmental and social risks in China's unconventional gas secto lessons learned and application in future developments," Society of Petroleum Engineers, pp. 351-360, 2012.

[3] Y. Xu, and E. Chan "Community question in transitional china a case study of state-led urbanization in shanghai," Journal of Urban Planning and Development, vol.4, pp. 416-424, 2012.

[4] B. Y. Liu and W. Chen, "Reflections on China's current rural landscape planning and construction," Construction Of Small Towns, vol. 9, pp. 45-47, 2005.

[5] S. Shackleton, A. Chinyimba, P. Hebinck, C. Shackleton, and H. Kaoma, "Multiple benefits and values of trees in urban landscapes in two towns in northern South Africa," Landscape and Urban Planning, vol. 6, pp.76-86, 2015.

[6] J. Q. Sun, and R. J. Wamg, "Morphological analysis of the traditional street space and modern heritage - a case study of Chongqing Ciqikou," Modern Decor Theory, vol. 2, pp.140-141, 2012.

[7] R. Picone, "Vernacular architecture in Campania Felix: Values and conservation problems Vernacular Architecture: Towards a Sustainable Future," In: Proceedings of the International Conference on Vernacular Heritage, Sustainability and Earthen Architecture, pp.625-630, 2015.

[8] B. Ozel, L. Dipasquale, and S. Mecca, "Resilience and intangible heritage of vernacular architecture. Vernacular Architecture: Towards a Sustainable Future," In: Proceedings of the International Conference on Vernacular Heritage, Sustainability and Earthen Architecture, pp.571-576, 2015. 
[9] L. Kevin, and H. Gary, "The overall design," Beijing, China Building Industry Press,pp.159, 1999.

[10] L. Y. Shen, and Z. W. Wang, "Pleasant residential area of landscape spatial scales --- Qingdao Luxin Changchun Garden Case," Northwest Forestry University, vol. 1, pp.191-195, 2012.

[11] J. Yan, J. Wang, Y. Feng, "The settlement pattern and vernacular architecture research," Sichuan Building Science, vol. 3, pp.300303,2012
[12] F. W. Tan, "The ecological characteristics of chinese traditional architecture," Applied Mechanics and Materials, pp. 1793-1796, 2014.

[13] S. Park, Ç. C. Hepcan, E. Hepcan, and E. A. Cook, "Influence of urban form on landscape pattern and connectivity in metropolitan regions: a comparative case study of Phoenix," Environmental Monitoring and Assessment, vol. 10, pp.6301-6318, 2014.

Received: June 10, 2015

Revised: July 29, 2015

Accepted: August 15, 2015

(C) Huang Yan; Licensee Bentham Open.

This is an open access article licensed under the terms of the (https://creativecommons.org/licenses/by/4.0/legalcode), which permits unrestricted, noncommercial use, distribution and reproduction in any medium, provided the work is properly cited. 